\title{
Exploring the antecedents of the mental health of business professionals in Sweden
}

Timur Uman, Pernilla Broberg and Torbjörn Tagesson

The self-archived postprint version of this journal article is available at Linköping University Institutional Repository (DiVA):

http://urn.kb.se/resolve?urn=urn:nbn:se:liu:diva-172645

N.B.: When citing this work, cite the original publication.

Uman, T., Broberg, P., Tagesson, T., (2020), Exploring the antecedents of the mental health of business professionals in Sweden, Work, 67(3), 665-669. https://doi.org/10.3233/WOR-203316

Original publication available at:

https://doi.org/10.3233/WOR-203316

Copyright: IOS Press

http://www.iospress.nl/ 
Exploring the antecedents of mental health of the business professionals

\author{
Timur Uman, $\mathrm{PhD}^{1,2 *}$ \\ Pernilla Broberg, $\mathrm{PhD}{ }^{1,3}$ \\ Torbjörn Tagesson, $\mathrm{PhD}^{3}$
}

${ }^{1}$ Department of Business

Kristianstad University

29188 Kristianstad

Sweden

${ }^{2}$ Jönköping International Business School

Jönköping University

55318 Jönköping

Sweden

${ }^{3}$ Department of Management and Engineering,

Linköping University

Linköping

Sweden

*Corresponding authors: timur.uman@ju.se 
Conflict of interest: None to declare

Ethical approval: N/A

Acknowledgments: N/A

Funding information: Civilekonomer / Platform for Enterprising at Kristianstad University 


\title{
Exploring the antecedents of the mental health of business professionals in Sweden
}

\begin{abstract}
BACKGROUND: Business professionals are an important occupational group that carries responsibility for the economic welfare of organizations and of society at large. These professionals have recently been reported to be experiencing increased mental strain, which may have a significant effect on the role they play in organizations and in society. Understanding the causes of this strain is thus an important endeavour.
\end{abstract}

OBJECTIVE: This study explores the antecedents of the mental health of business professionals.

METHODS: Multiple linear regression analyses were used to examine the relationship between business professionals' mental health and its demographic, work-related, and other triggers. Ttests and descriptive statistics were used to explore the gender of the respondents in relation to these triggers and mental health.

RESULTS: Compared with their male counterparts, female business professionals report poorer mental health; however, no gender differences were found in job satisfaction or life satisfaction. According to this study, age, overtime pay, higher salary and position as a manager have a positive relation with mental health, whereas working overtime has a negative relation with mental health. Job satisfaction and life satisfaction are important determinants of the mental health of business professionals.

CONCLUSIONS: Business professionals are important to the economic welfare of their organization and of society as a whole. Our study suggests that demographic characteristics, work- 
related aspects and subjective dimensions of well-being have a profound effect on the mental health of business professionals.

Key terms: Antecedents, business professionals, mental health, occupational health 


\section{Exploring the antecedents of the mental health of business professionals in Sweden}

\section{Introduction}

The well-being of business professionals is attracting increasing interest in the social and medical sciences [1-3]. Studies on this topic often focus on specific contexts in which business professionals are employed. For example, recent studies have explored the well-being of auditors [4] and bankers [5], and have thus focused on professional groups that require a business degree for entry. Yet business professionals are present in all types of organizations and do not necessarily belong to narrowly defined professions. For example, accountants and business controllers work in state, municipal and private organizations, and individuals with business degrees work in marketing and branding. Thus, recent studies have only uncovered dimensions of well-being within narrowly defined contexts, rather than identifying those of individuals with business-related assignments in a variety of organizations. It is important to understand the well-being of business professionals as a group, rather than in a specific context, since this group is vested with the important function of administering economic resources in a wide range of organizations [6]. Previous research has shown that workers' efficiency in performing their professional functions is tightly interconnected with their well-being [7]. Thus, understanding which factors contribute to business professionals' well-being is important in order to support such professionals in their contributions to the economic welfare of their organizations and of society. Another motivation behind this study is to address the increasing amount of sick leave being taken by business professionals [8]. Recent surveys conducted by the labour union Civilekonomerna (the Swedish Association of Graduates in Business Administration and Economics) suggest that business professionals take sick leave as a result of job related stress [9]. This finding emphasizes the significance of the mental health of business professionals and of the factors that contribute to it. 
Studies exploring the mental health of occupation groups have revealed a number of antecedents of considerable importance. These studies suggest that aspects such as income [10], gender [11] and age [12] influence mental health. Taking these findings into account, this study aims to explore the antecedents of the mental health of business professionals.

\section{Method}

Data collection was carried out in the autumn of 2017 in cooperation with Civilekonomerna, a Swedish trade union with approximately 44,000 members (mainly business professionals), which annually surveys its members' wages and employment situation. The survey was administered and distributed by the union via email. The union allowed us to design and add a section with questions measuring mental health and subjective well-being (which was not previously included in the survey). Nearly 11,000 members responded, and 8,792 responses were found to be useful for this study. ('Usefulness' was determined by whether or not the respondents answering the questions regarding mental health and well-being were working when the survey was distributed in October 2017). The mean age of the 'useful' respondents was 43.70 years (range 22.88-71.97); 5,085 (57.5\%) respondents were women and 3,734 (42.5\%) were men.

To measure the dependent variable - that is, mental health - the General Health Questionnaire (GHQ-12) was used. The GHQ-12 is a widely used unidimensional self-assessment instrument that focuses on respondents' experiences over the preceding two weeks, with 12 questions measuring psychological health problems. It includes dimensions of (1) anxiety and depression, (2) social dysfunction and (3) loss of confidence [13], along with questions on being able to concentrate, experiencing loss of sleep (due to worrying), playing a useful part in things, being capable of making decisions, being under constant strain, facing up to everyday problems, being reasonably happy, being unable to overcome difficulties, being unhappy or depressed, losing confidence in oneself, thinking of oneself as worthless and enjoying day-to-day activities. The 
respondent is asked to answer each of the 12 questions using a four-point scale $(0=$ not at all, $1=$ the same as usual, $2=$ rather more than usual or $3=$ much more than usual).

The GHQ-12 score was calculated using a Likert method in which the score can vary from 0 to 36 points; this method provides a broad range of points that can be used when measuring the degree of mental health and when comparing groups. A high score indicates a potential risk for psychiatric problems (i.e. poor mental health). Scores may vary according to population, according to previous studies [14]. Use of the GHQ-12 can be sensitive to gender, social class membership, employment status and cultural background; this sensitivity is one of its limitations.

Two subjective measures of well-being were included - job satisfaction and life satisfaction - due to their importance in relation to professional well-being in an organizational context (cf. $[15,16])$. These variables were measured with a single question each (i.e. How satisfied or dissatisfied are you with your current job/life?) and a seven-point Likert scale was used for response options (from $1=$ not at all satisfied to $7=$ completely satisfied).

To explore the antecedents of mental health, we used both demographic and employment-related variables. The demographic variables included gender (female/male), age and monthly salary (TSEK). The employment-related variables included employment change $(0=$ the same employer as one year ago, i.e. October 2016; 1 = changed employer since October 2016); overtime compensation $(0=$ no overtime compensation, $1=$ overtime compensation in the form of money and/or time off $)$; overtime hours $(0=$ never works overtime, $1=1-8 \mathrm{~h}$ per month, $2=9-16 \mathrm{~h}$ per month, $3=17-31 \mathrm{~h}$ per month and $4=$ more than $32 \mathrm{~h}$ per month $)$; position as a manager $(0=$ not a manager, 1 = operational, budget and/or personnel manager $)$; and sector $(0=$ employed in any sector other than the public sector, $1=$ employed by the state, municipality or county).

\section{Results}


Table 1 presents descriptive statistics for the data, displays the sample by gender and reports on gender differences in relation to the variables. The results of the t-tests, which related to different aspects of the respondents' mental health and well-being, indicated that the women had a significantly higher average GHQ-12 score (mean 14.44) than the men (mean 13.56). However, no significant differences were found between women and men in terms of job satisfaction or life satisfaction. Our results also indicated that the men were significantly older, worked more overtime hours and had a higher salary than the women in the sample. Furthermore, the men received significantly less overtime compensation than the women and occupied more managerial positions. Finally, Table 1 shows that in our sample, more women than men were employed in the public sector.

Insert Table 1 about here

Table 2 reports the results of multiple linear regression analyses in which the GHQ-12 score is a dependent variable. Model 1 provides results that do not include subjective measures of well-being (job satisfaction and life satisfaction). Model 2 provides results that include these two measures, which are conceptually different from the measures of mental health represented by the GHQ score. The results of the regression analysis in Model 1 indicate that increasing age, a recent change of employer, overtime compensation, higher salary and a position as manager have a significant positive relation with mental health. Being female and working an increasing number of overtime hours have a significant negative relation with mental health. The results of Model 2 are very similar to those of Model 1, apart from employer change becoming insignificant and the additional variables of job satisfaction and life satisfaction showing a significant positive relation with mental health. Models 3 and 4 provide results for male respondents, while Models 5 and 6 provide results 
for female respondents. It appears that the antecedents of mental health are of equal importance (or unimportance) across genders. However, in Models 3 and 5, age has no significant relation with mental health, whereas in Models 4 and 5, age is reduced in comparison with the total sample in terms of the relation to the GHQ. Furthermore, in Models 4 and 6, overtime compensation is reduced in a positive relation to the GHQ, in comparison with the total sample in Model 2.

Insert Table 2 about here

It is notable that Models 2, 4 and 6, which include the job and life satisfaction dimensions of wellbeing, have a considerably higher adjusted R-squared (adj. $\mathrm{R}^{2}$ of $27.8 \%-29.7 \%$ ) than Models 1,3 and 5, which do not include these dimensions (adj. $\mathrm{R}^{2}$ of $\left.3.6 \%-6 \%\right)$.

\section{Discussion}

This study aimed to explore the antecedents of the mental health of business professionals who are members of the Swedish labour union Civilekonomerna. The results of a survey issued by the union and modified by us showed that the women's mental health was significantly poorer than that of the men in this sample. These findings resonate with the literature on occupational health, which shows that women experience considerably higher mental strain than men [17]. The current study also shows that the job and life satisfaction aspects of well-being do not differ between women and men. These two aspects have considerable explanatory power in predicting the mental health of both genders, as has been indicated in previous literature [18-20]. Our study further shows significant differences between the salaries of males and females, with those of males being considerably higher. We also found that salary is an important antecedent of the mental health of business professionals, irrespective of gender. 
Our study suggests that work-related aspects such as overtime compensation, a managerial position and overtime hours are related to business professionals' mental health. While the first two aspects have a positive relation with mental health, the third aspect has a negative relation with mental health. Finally, our study indicates that employment in either the public or private sector is not a factor in mental health.

The strength of this study lies in its use of nationwide data, from which extensive information was gained on both factual demographic aspects and work-related aspects, along with more subjective data on mental health and well-being (i.e. job and life satisfaction). The limitation of our sample is its lack of data on non-work-related aspects, such as family situation and individuals' personal network. This study might also suffer from respondent bias, although the Harman's single-factor test [21] that was performed indicated low bias probability.

In conclusion, this study suggests that the mental health of business professionals is affected by triggers that are demographic, work-related and subjective in nature. The findings also show that business professionals in Sweden are experiencing relatively low levels of mental health. Should this situation persist, the economic welfare of Swedish society may be negatively affected. 


\section{References}

[1] Giahi O, Shahmoradi B, Barkhordari A, Khoubi J. Visual display terminal use in Iranian bank tellers: Effects on job stress and insomnia. WORK 2015; 52(3): 657-62.

[2] Kan D, Yu X. Occupational stress, work-family conflict and depressive symptoms among Chinese bank employees: The role of psychological capital. Int. J. Environ. Res. Public Health 2016; 13(1): 134.

[3] Giorgi G, Arcangeli G, Perminiene M, Lorini C, Ariza-Montes A, Fiz-Perez J, DiFabio A, Mucci N. Work-related stress in the banking sector: A review of incidence, correlated factors, and major consequences. Front Psychol. 2017; 8: 2166.

[4] Umans T, Broberg P, Schmidt M, Nilsson S, Olsson E. Feeling well by being together: Study of Swedish auditors. WORK 2016; 54(1): 79-86.

[5] Mughal F, Ahmad M, Gondal AM, Awan TM, Chaudhry IG. Repercussions of stressors on employee work-life balance: Analysing the banking industry of Pakistan. J. for Glob. Bus. Adv. 2010; 3(4): 325-47.

[6] Noordegraaf M. Reconfiguring professional work: Changing forms of professionalism in public services. Adm. \& Soc. 2016; 48(7): 783-810.

[7] Siegrist J, Wahrendorf M, Von dem Knesebeck O, Jürges H, Börsch-Supan A. Quality of work, well-being, and intended early retirement of older employees - baseline results from the SHARE Study. The Eur. J. of Pub. Health 2007; 17(1): 62-8.

[8] Callius S. Sjukskrivningarna ökar bland landets ekonomer [Sick leave days are increasing among Swedish business professionals]. Civilekonomer Tidning [Business professionals' magazine] 2015. Available from: https://www.civilekonomen.se/agenda/sjukskrivningarna-okarbland-landets-ekonomer/.

[9] Psykisk ohälsa ökar bland ekonomer [Mental health increases among business professionals] [Internet]. Kurera 2018. Available from: https://kurera.se/psykisk-ohalsa-okar-bland-ekonomer/. 
[10] Deaton A. Income, health, and well-being around the world: Evidence from the Gallup World Poll. J. Econ. Perspect. 2008; 22(2): 53-72.

[11] Buhmann B, Rainwater L, Schmaus G, Smeeding TM. Equivalence scales, well-being, inequality, and poverty: Sensitivity estimates across ten countries using the Luxembourg Income Study (LIS) database. Rev. Income Wealth 1988; 34(2): 115-42.

[12] Wright TA, Cropanzano R. The role of psychological well-being in job performance: A fresh look at an age-old quest. Organ Dyn. 2004; 33(4): 338-51.

[13] Gao F, Luo N, Thumboo J, Fones C, Li S-C, Cheung Y-B. Does the 12-item General Health Questionnaire contain multiple factors and do we need them? Health and Qual. of L Outcomes 2004; 2(1): 63 .

[14] Sconfienza C. Mätning av psykiskt välbefinnande bland ungdomar i Sverige [Measuring psychological well-being among youth in Sweden]. Användning av GHQ-12 [The use of GHQ12]. Arbete och Hälsa Vetenskaplig skriftserie [Work and Health Scientific Series] ISBN 917045-493-0, ISSN 0346-7821. 1998.

[15] Andrews FM, Withey SB. Developing measures of perceived life quality: Results from several national surveys. Soc. Indic. Res. 1974; 1(1): 1-26.

[16] Diener E, Emmons RA, Larsen RJ, Griffin S. The satisfaction with life scale. J. Pers. Assess. 1985; 49(1): 71-5.

[17] Emslie C, Fuhrer R, Hunt K, Macintyre S, Shipley M, Stansfeld S. Gender differences in mental health: Evidence from three organisations. Soc. Sci. Med. 2002; 54(4): 621-4.

[18] Cooper CL, Sutherland VJ. Job stress, mental health, and accidents among offshore workers in the oil and gas extraction industries. Journal of Occupational Medicine: Official Publication of the Industrial Medical Association 1987; 29(2): 119-25. 
[19] Prosser D, Johnson S, Kuipers E, Szmukler G, Bebbington P, Thornicroft G. Mental health, 'burnout' and job satisfaction among hospital and community-based mental health staff. The British J. of Psycol. 1996; 169(3): 334-7.

[20] Happell B, Martin T, Pinikahana J. Burnout and job satisfaction: A comparative study of psychiatric nurses from forensic and a mainstream mental health service. Int. J. Ment. Health Nurs. $2003 ; 12(1): 39-47$.

[21] Podsakoff PM, MacKenzie SB, Lee J-Y, Podsakoff NP. Common method biases in behavioral research: A critical review of the literature and recommended remedies. J. Appl. Psychol. 2003; 88(5): 879 . 


\section{Table captions}

Table 1. Descriptive statistics and gender differences ( $\mathrm{SD}=$ standard deviation)

Table 2. Antecedents of GHQ-12 score $(\mathrm{TS}=$ total sample; $\mathrm{MO}=$ males only; $\mathrm{FO}=$ females only $)$ 
Table 1. Descriptive statistics and gender differences ( $\mathrm{SD}=$ standard deviation)

\begin{tabular}{|c|c|c|c|c|c|c|c|c|}
\hline \multirow{2}{*}{ Variables } & \multicolumn{3}{|c|}{ Total sample $(\mathrm{n}=8792)$} & \multicolumn{3}{|c|}{ Women $(\mathrm{n}=5058)$} & \multicolumn{2}{|c|}{$\operatorname{Men}(n=3734$} \\
\hline & Mean & $\mathrm{SD}$ & $\%$ & Mean & $\mathrm{SD}$ & $\%$ & Mean & SD \\
\hline GHQ score & 14.07 & 2.83 & & 14.44 & 2.840 & & 13.56 & 2.736 \\
\hline Age & 43.70 & 10.12 & & 43.26 & 9.915 & & 44.19 & 10.381 \\
\hline Employment change & & & 19.0 & & & 19.2 & & \\
\hline $\begin{array}{l}\text { Overtime } \\
\text { Compensation }\end{array}$ & & & 52.3 & & & 56.5 & & \\
\hline Overtime hours & 1.35 & .993 & & 1.28 & 0.952 & & 1.45 & 1.039 \\
\hline Salary & 52.90 & 24.68 & & 48.55 & 19.045 & & 58.79 & 29.705 \\
\hline Manager & & & 28.5 & & & 25.0 & & \\
\hline Public sector & & & 16.8 & & & 19.8 & & \\
\hline Job satisfaction & 5 & 1.38 & & 4.99 & 1.369 & & 5.02 & 1.386 \\
\hline Life satisfaction & 5.56 & 1.11 & & 5.56 & 1.098 & & 5.57 & 1.132 \\
\hline
\end{tabular}


Table 2. Antecedents of GHQ-12 score ( $\mathrm{TS}=$ total sample; $\mathrm{MO}=$ males only; $\mathrm{FO}=$ females only)

\begin{tabular}{|c|c|c|c|c|c|c|c|c|}
\hline \multirow{3}{*}{ Variables } & \multirow{2}{*}{\multicolumn{2}{|c|}{$\begin{array}{c}\text { Model } 1 \text { (TS) } \\
(\mathrm{n}=8792)\end{array}$}} & \multirow{2}{*}{\multicolumn{2}{|c|}{$\begin{array}{c}\text { Model } 2 \text { (TS) } \\
(\mathrm{n}=8792)\end{array}$}} & \multirow{2}{*}{\multicolumn{2}{|c|}{$\begin{array}{c}\text { Model } 3(\mathrm{MO}) \\
(\mathrm{n}=5058)\end{array}$}} & \multirow{2}{*}{\multicolumn{2}{|c|}{$\begin{array}{c}\text { Model } 4(\mathrm{MO}) \\
(\mathrm{n}=5058)\end{array}$}} \\
\hline & & & & & & & & \\
\hline & $\beta$ & S.E. & $\beta$ & S.E. & $\beta$ & S.E. & $\beta$ & S.E. \\
\hline Age & $-.030 * *$ & .003 & $-.035 * * *$ & .003 & -.026 & .005 & $-.034^{*}$ & .004 \\
\hline Gender & $.136^{* * *}$ & .061 & $.141 * * *$ & .052 & & & & \\
\hline $\begin{array}{l}\text { Employer } \\
\text { change }\end{array}$ & $-.054 * * *$ & .077 & -.013 & .067 & $-.055^{* * *}$ & .103 & -.015 & .090 \\
\hline $\begin{array}{l}\text { Overtime } \\
\text { Compensation }\end{array}$ & $-.073 * * *$ & .063 & $-.039 * * *$ & .055 & $-.072 * * *$ & .085 & $-.040 * *$ & .047 \\
\hline Overtime hours & $.118^{* * *}$ & .032 & $.080 * * *$ & .028 & $.153 * * *$ & .044 & $.100 * * *$ & .039 \\
\hline Salary & $-.117 * * *$ & .002 & $-.055 * * *$ & .001 & $-.126^{* * *}$ & .003 & $-.066^{* * *}$ & .002 \\
\hline Manager & $-.111 * * *$ & .074 & $-.059 * * *$ & .065 & $-.099 * * *$ & .104 & $-.053 * * *$ & .091 \\
\hline Public sector & .004 & .082 & .009 & .071 & .006 & .103 & .009 & .090 \\
\hline Job satisfaction & & & $-.303 * * *$ & .020 & & & $-.321 * * *$ & .021 \\
\hline Life satisfaction & & & $-.295 * * *$ & .025 & & & $-.280 * * *$ & .033 \\
\hline Constant & $14.723 * * *$ & .161 & $21.572 * * *$ & .191 & $25.551 * * *$ & .228 & $22.529 * * *$ & .273 \\
\hline F-value & 71.66 & & 371.9 & & 32.00 & & 217.1 & \\
\hline Sig. & .000 & & .000 & & .000 & & .000 & \\
\hline Adj. $\mathrm{R}^{2}$ & $6 \%$ & & $29.7^{\circ}$ & & $4.1 \%$ & & $27.8^{\circ}$ & \\
\hline Highest VIF & 1.63 & & 1.64 & & 1.74 & & 1.758 & \\
\hline
\end{tabular}

